\title{
Reflections of Society in Art: Contributions of Michael Soi's Politics Paintings to Socio-Political Debates in Africa
}

\author{
Chijioke Onuora', Krydz Ikwuemesi², Chukwuemeka Okpara³ \& Emeka \\ Aniago ${ }^{4}$ \\ ${ }^{1}$ Senior Lecturer, Dept. of Fine E Applied Arts, University of Nigeria, Nsukka, Nigeria \\ ${ }^{2}$ Associate Professor, Dept. of Fine E Applied Arts, University of Nigeria, Nsukka, Nigeria \\ 3 Senior Lecturer, Dept. of Fine E Applied Arts, University of Nigeria, Nsukka, Nigeria \\ 4 Senior Lecturer, Dept. of Theatre E Film Studies, University of Nigeria, Nsukka, Nigeria \\ ORCID id oooo-00o3-3194-1463. Email: emekaaniago@gmail.com
}

\begin{abstract}
The purpose of this study is to extend scholarly reading of the contributions of Michael Soi's politics paintings to social debates as a means of deepening our understanding of the complex relationship between art and politics. Thus, this study assesses relevant variables indicating how Soi's selected paintings are effectively his means of projecting his views about his experiences, expectations, dreams, fears and reservations concerning his society's socio-political realities. In an attempt at analyzing the functionality and aesthetic significances of Soi's paintings, this study discusses relevant perspectives from individuals on politics paintings particularly how they can propel meaningful debates. Therefore, to gather relevant information on people's responses to this kind of painting, we utilized viewer response approach and follow-up interviews. More so, we applied interpretive analysis in assessing the paintings (as metaphors depicting social realities), the collated responses (as means of espousing more on the concepts of cognitive process mechanisms), and relevant literature (as a means of assessing the trajectories of scholarly views on this subject). In the end, we observe that Soi's politics paintings are efficacious medium of communication and that each individual viewer of these paintings produces responses that are similar or dissimilar but not exact because their subsisting ideological, political and philosophical inclinations are not exactly the same.
\end{abstract}

Keywords: Africa, art, cognition, efficacy, Michael Soi, politics painting

\section{Introduction}

Our current study explores six politics paintings of Michael Soi, in a bid to deepen our knowledge of his works' contributions to socio-political debates in Kenya and beyond concerning postcolonial Chinese dominant presence in parts of Africa. As part of our focus, we are attempting to illuminate interpretively on the aesthetics, artistic, and creative sublime imperatives of the techniques and styles (particularly the shades of semiotics and symbolism) Soi deployed in the paintings under study. Hence, we shall interpret analytically the qualities of the paintings in relation to how they depict possible narratives and their communication efficacy. In addition, we shall examine factors propelling suppositions expressing why some of the aspects of these paintings' depictions are describable as positive or negative representations by various individuals; and adumbrate on their power of presence. To place our discussion in proper

(C) AesthetixMS 2021. This Open Access article is published under a Creative Commons Attribution Non-Commercial 4.0 International License (http://creativecommons.org/licenses/by-nc/4.o/), which permits non-commercial re-use, distribution, and reproduction in any medium, provided the original work is properly cited. For citation use the DOI. For commercial re-use, please contact editor@rupkatha.com. 
perspective, we shall first explain the expression politics painting; present clearly it relevance and contexts of application in this paper. More so, we shall look at the relationship between art and politics.

\section{Relationship between Art and Politics: Theory and Practice}

The definition of art remains a subject of various ongoing scholarly debates because there is no consensus. Naturally, each attempt at defining art instigates more questions and debates, thus Thomas Adajian observes that the definition of art "is controversial in contemporary philosophy" and "whether art can be defined has also been a matter of controversy" (2018: 1). Virtually all visible definitions of art and the counter arguments are in accord that art is an efficacious medium of communication, through which artists encode ideas, emotions, information, worldviews and knowledge for viewers' interpretation, reflection, appreciation, fulfilment and enrichment (see Weitz 1956; Dickie 1984; Eagleton 1990; Levinson 1990; Janaway 1998; Shiner 2001; Dean 2003; Adajian 2018; Okpara et al 2020). Another widely held view is that arts are in many ways, products of societies and in essence, they reflect specificities as well as universal commons of societies, in one way or another. In line with these suppositions, Alex Danchev notes that "art articulates a vision of the world that is insightful and consequential" and that "the vision and the insight can be analyzed" variously (2009: 4). Hence, several scholarly contributions indicate that some works of art possess varying efficacy potentials and propensity to stimulate and sustain discussions about subsisting socio-economic realities, history, and can subconsciously propel notions (see Groys 2008; Haas 2011 Demirel \& Altintas 2012; Goehr 2014; \& Okpara et al 2020). Also several plausible scholarly reports, observe that some arts at varying degrees possess the propensity, to rouse or dowse emotions; to recalibrate, twist or re-aggregate people's worldviews, ideologies, and inclinations; to reinvent myths and legends; and to heal, revive, infuriate or emotionalize people (see Dickie 1997; Tan 2000 \& Gorman 2015).

Espousing, Gorman notes that "artists have power" and this is "the power not just to create, but also to transform" because "for as long as 'art' has existed, it has been 'socially-engaged"' (2015: 4). Furthering, Gorman adds that "political art, socially-engaged art, art activism, is nothing new" because "we could, for example, count several ancient Greek plays as the work of "political activists"' (2015: 4). Elaborating further on the application of art as a medium of socio-political engagement, Gorman observes that there are instances whereby "individual artists engaged topics ranging from women's liberation to race equality, from an end to colonial rule to LGBTQ rights" (2015: 4).

Another view that is widely held is that all forms of art emerge from one or a combination of different source materials (see Castor 1964; Allen 1999; Eckert \& Stacey 2000; Okada \& Ishibashi 2017; \& Okpara et al 2020). Having looked at the contributions of several scholars, we are classifying these source materials as either consciously or subconsciously based information sources. The consciously acquired information sources for arts include personal experiences, stories of experiences of others received orally; information seen in films and other electronic media, extracted from books, heard in songs, seen in dances and in everyday activities, assimilated from pre-existing arts and observed in phenomena of nature and environment. Whereas the subconscious sources of information are recollections of dreams, trance, meditations, apparitions, and prophecies.

Articulating the process of harnessing arts source materials, Claudia Eckert and Martin Stacey observe that "almost all designs, proceed by transforming, combining and adapting elements of 
previous designs, as well as elements and aspects of other objects, images and phenomena" and that "everything can be a source of inspiration to a designer" (2000: 524).

Just as we attempt to explain elaborately the classification of Soi's source materials for his paintings, there are examples that elucidate our perspective. In relation to our postulations on the source materials of politics and ideologically driven paintings, the works of several artists depict this reality. For instance, Pablo Picasso's Guernica is a 1937 anti-war oil painting on canvas, which portrays the affliction of people and animals due to the bombing of Guernica, a Basque Country town in northern Spain, by Fascist Italy and Nazi Germany during the Spanish civil war (see Oppler 1988; Rhodes 2013). Similarly, Otto Dix who lived from 1891 to 1969 is renowned for his depictions of indigent war veterans and prostitutes after his service in the German Army during World War 1. He also painted satirical portraits of members of the upper echelons of German society, such as Dr. Mayer-Hermann, 1926. This painting comments on the life of excess led by the thriving middle class of the Weimar Republic (see Singh 2012; Patel 2016). Likewise, Diego Rivera who lived from 1886 to 1957 is a Mexican artist who is renowned for his murals depicting events related to important socio-political realities in Mexican history. Some of his works also reflect his visits to Europe on multiple occasions in the early twentieth century, where he experienced both the avant-garde trends of Paris and the Renaissance fresco tradition from Italy. Rivera created this Lithograph depicting land reform and socio-revolutionary leader Emiliano Zapata, dressed in simple white peasant clothing, twelve years after the end of the Mexican Revolution. This art depicts Zapata standing over the lifeless figure of a soldier, with his horse beside him. Zapata and his followers (the farm workers he strives to defend) are carrying farming tools as weapons, suggesting their close ties to the land, which are in contrast to the soldier's sword (see Hurlburt 1989; Ittmann 2006). Similarly, the Nigerian artist Obiora Udechukwu in a number of in his works depicts deep grief and melancholy of ordinary people, which he witnessed during Nigerian civil war. Some of these works are The Exile train (1968, linocut); Lament of the Widowed Woman, (1967, linocut); The Man Died, (1970, watercolour); Refugee Children, (1970, oil on board); Blue Figures (Refugees), (1968, oil on plywood); Lament of the Unsilenced (1967, oil on board); and The Only Son, (1968, oil on plywood) (see Okpara et al 2020).

Meanwhile, scholarly attempts at deepening people's understanding of the inter-relationship complexity between arts and politics in general remain a long-standing academic endeavour with evident areas of interests open to multidisciplinary interpretations and methodological pluralism. However, some categories of arts, such as politics music, propaganda literature, revolutionary drama and politics painting, appear more likely to influence and instigate political debates.

The expression politics painting suggests a category of paintings that are potent medium of political engagement. To understand our application of the expression politics painting in this discussion, we shall look at interpretations of the word politics. According to Iain McLean and Alistair McMillan, "the definition of politics is highly, perhaps essentially contested" even though as a general concept, it denotes "the practice of the art or science of directing and administering states or other political units" (2009: 423). Looking at the contestations surrounding what politics represents, McLean \& McMillan observe; "there is considerable disagreement on which aspects of social life ought to be considered political" (2009: 423). Furthermore, they observe that, "the traditional definition of politics" as "the art and science of government, offers no constraint on its application, since there has never been a consensus on which activities count as government" (2009: 423). The position of McLean and McMillan were they rhetorically enquire whether the notion of government is confined only to the state, whether it takes place in church, guild, estate, 
and family, suggests that politics pervades every aspect of life were human-social units exist. In their attempt to explain politics, Paul Chilton and Christina Schaffner suggest that politics represents "a struggle for power, between those who seek to assert and maintain their power and those who seek to resist it" (2002: 5). It is also the view of Chilton and Schaffner that politics subsumes nuances and modalities of "cooperation, as to the practices and institutions a society has in resolving clashes of interest over money, power, liberty and the like" (2002: 5). Thus, the contribution of Chilton and Schaffner accord with our view that politics is about various ways and processes people deploy in enthroning, sustaining, checking, and dismantling of government and governance in adherence to their individual and common interests. Therefore, in the context of this paper, we observe that politics is about choices and interests of people wherever the need for governance and institutional process exit, the process of selecting and enthroning of individuals who will govern the people, the mechanics of assessing their conducts and the continual quests to be part of engagement in governance in any form. Therefore, the understanding that art reflects the society is an aspect of human reality, which people take seriously because of its propensity to create interpersonal and communal disharmony, its capacity to disenchant the ruling class or the masses, which is the underpinning reality of politics art and paintings. We also have to recognize that some politics paintings available in the public domain possess the propensity to instigate and re-aggregate inclinations. Consequently, this leads us to ask whether it is possible for art's articulation to be of any consequence to individuals and the society. More so, by what parameters shall we sufficiently analyze the vision and consequential essence of politics art and paintings?

In response to this question, we turn to Frank Möller who observes; "art can be understood as a form of political discourse; as a descriptive, an interpretive, or an explicitly critical approximation; or as a vehicle with which to transcend the political" (2018: 1). To view art such as Michael Soi's paintings in the series 'China Loves Africa' as a form of political discourse or a medium of political engagement is to analytically explain the relationship between politics and these paintings, which involves assessing what we are referring to as 'quality of artistic engagement'. In this regard, a painting's 'quality of artistic engagement' is subsumed in its aesthetic and creative nuances such as ambiance of intensity, ambiguity, simplicity, realism, obscurity and ferocity of its codification of a vision of the world it is representing. Thus, there is a need to clearly explain two key aspects of this sub-section, namely 'depiction of politics in paintings' and 'quality of artistic engagement' so that we can appreciate how their meanings can help us elucidate more on ways of anchoring our discussion on the relationship between politics and painting in relation to Michael Soi's politics paintings.

According to Candess Kostopoulos, it is plausible "to claim that art has values that transcend or reach beyond the so-called autonomously aesthetic" (2011: 523). This statement by Kostopoulos subsumes the view that art's utilities and functions, go way beyond the presentation of an aesthetic presence alone, but include projection of strong and efficacious ambiance, which encodes emotions, multiple layers and shades of information and knowledge, didacticism, and political realities. Therefore, depiction of politics and its attendant nuances in paintings, suggest that paintings as texts, embody representations, pictures or images that can be unambiguously but differently interpreted by different individuals. These interpretations can be either literal or metaphorical codification of social realities which are describable to them in their understanding as specific political commentary or commentaries. Thus, the question is what constitutes political commentary in art and painting? One way of looking at it according to John Elderfield is to say that "art is political if it complicates, not simplifies", and if it "extends the thread of recognition and understanding beyond what previously was seen and known" (2006: 44). Another way of looking at it according to Jacques Ranciere is to say that "art is presumed to be effective politically 
because it displays the marks of domination, or parodies mainstream icons, or even because it leaves the spaces reserved for it and becomes a social practice" (2010: 134 - 135). Presenting another interpretation, Paul Mattick notes that "what art is changes with people's conceptions of the tasks of art, conceptions that are themselves a part of social history" and "the history of society does not shape art from the outside, but includes the attempts of artists to find new ways of making art and thinking about it" (2003: i). In her contribution touching on functionality of politics art, Johanna Drucker observes that "artwork termed 'political' often serves a stabilizing function, helping to maintain the cultural status quo" (2005: 3). Furthering Drucker notes that throughout the twentieth century "the appearance of radicalism cloaked the careerism of many artists," however "the oppositional rhetoric of radicality in fine art and criticism has become formulaic and academic in the worst sense" (2005: 5). In line with increasing global reaching platforms and mediums of expression and communication, which artists equally enjoy in their ever growing representations of world's realities, Drucker's observation points at the need for an "admission of complicity, in which self interest plays a part, rather than a claim to 'resistance,' or 'aloof separation,' or 'distance" (2005: 11). This is because self-interest acts as a motivating factor, which propels some artists in their aesthetic radicalism.

Now if we align with the view that art is in many ways an embodiment of metaphor, it means that the interpretive readings of paintings will no doubt yield divergent and shifting interpretative outcomes and suppositions. This is because of human pre-existing inclinations, interests, worldviews, philosophies, cognition density and depth naturally influences their interpretation of things. Espousing on the relationship and interconnectedness between arts and society, Daniel Gorman after his extended interactions with several artists and deep reading of numerous artworks, observes that "arts and politics are inextricably linked to other topics like gender, globalisation, environment and economy" (2015:3). In many ways, the notion variously espoused by Elderfield, Gorman, and then Möller is that people are inclined to view art as political, if such a portrayal propels possible reinterpretations or overt glorification of political realities, which people widely know and acknowledge as political inclinations. In addition, art is termed political if it provides depictions or representations promoting an inclination, interest, or alternative understanding(s) capable disaffecting people because of their inclinations, status, race, ideologies and worldviews. Furthering on the context of interpretive reading of arts and paintings, we agree with Möller that the analysis of the interconnectedness between "politics and art is essentially pluralistic and multidisciplinary" which "come in many forms" and that "analysis of the visual arts includes critical investigation of the connection between what is seen and what is known" (2018: 6 - 8). Thus, what propels people to read and contextualize a painting as political according to Möller are their "pre-existing representational resources" (2018: 8). Meanwhile, these pre-existing representational resources are strictly ideas and worldviews individuals carry with them as memories generated from their conscious or subconscious information sources. The implication of this supposition is that no two individuals carry memory data of the same quality and quantity; hence, no two individuals will essentially decode a given art and arrive at exact conclusions. However, there are possibilities of close similarities in interpretation outcomes of the same art by two individuals and a possibility of largely dissimilar interpretation outcomes. Again, it is pertinent to state that depictions in paintings can complicate the observer's understandings and perceptions of the world, which the text supposedly encapsulates, thereby altering the discursive frames, which results in multiplicity of interpretation outcomes. Thus, a number of variables controlled by the density and depth of the human memory data in many ways influence an individual's interpretive outcomes on a painting. Such as the overall knowledge depth of the 
interpreter on a painting's thematic preoccupations in general, how deeply the painting the individual is interpreting represents the individual's personal realities, and the interpreter's knowledge of the painter's works, history and social realities. In the areas of possible multiple information and representation encoding in a painting, we suggest that interpreting a painting requires assessing the possibilities of the (inter)textual dimensions, pictorial projections, and aesthetic shades and nuances (see Der Derian \& Shapiro eds (1989); Mitchell (1994); Amado (2005), Bleiker (2009); Shapiro (2013).

\section{Michael Soi’s ‘China Loves Africa' Paintings}

In this section, we shall start by providing relevant biographical insight on Michael Soi; sufficient information on his arts in general with emphasis on his painting series tagged 'China Loves Africa', before we delve into the analysis of the six paintings in the above-mentioned series. Our analysis will revolve around the following variables. The artistic, aesthetic and creative sublime imperatives of Soi's techniques and styles in the six paintings; power and force of presence, narration and communication efficacy; reasons why the selected paintings may be viewed as positive or negative narratives by different individuals; and lastly the psychological insight illuminating the interconnectedness of the painter and his paintings.

Michael Soi was born in 1972 in Kenya and he graduated in 1996 from Buru Buru Institute of Fine Art in Nairobi were he settled and be began his art career as a sculptor. However, he became renowned and much more globally visible as a social critic, who applies satirical paintings as a platform for socio-political commentary and contestation focusing on Kenya and other African countries. He is a member of Kenya's 'Second Generation' of artists emerging in the late 1990s. His socio-political commentary paintings depict his readings of Sino-Africa trade relations and growing Chinese presence in sub-Saharan countries in a series, he tagged 'China Loves Africa' created within 2012 to 2013; his lampoon of the pervasive Nairobi sex industry, and intense satirical innuendo about lack of sufficient transparency by political leaders in Kenya.

Soi's satirical depiction in painting ' 1 ' includes eleven men wearing similarly tailored but different coloured suits and ties. Among them, one man whom he depicts as a Chinese is distinct from others because he is standing majestically in the middle of the group, wide-awake and alert. He depicts the remaining ten men who are leaning on each other's shoulders while dozing as black men, each representing an African country. These similarly tailored suits and ties metaphorically symbolize unhidden exhibition of alliance. The colours of the suits hardly designate any unambiguous attribution or symbolism, as regards to who they are or the country each represents. The application of different facial hues on the eleven men helps to suggest their racial identity. 


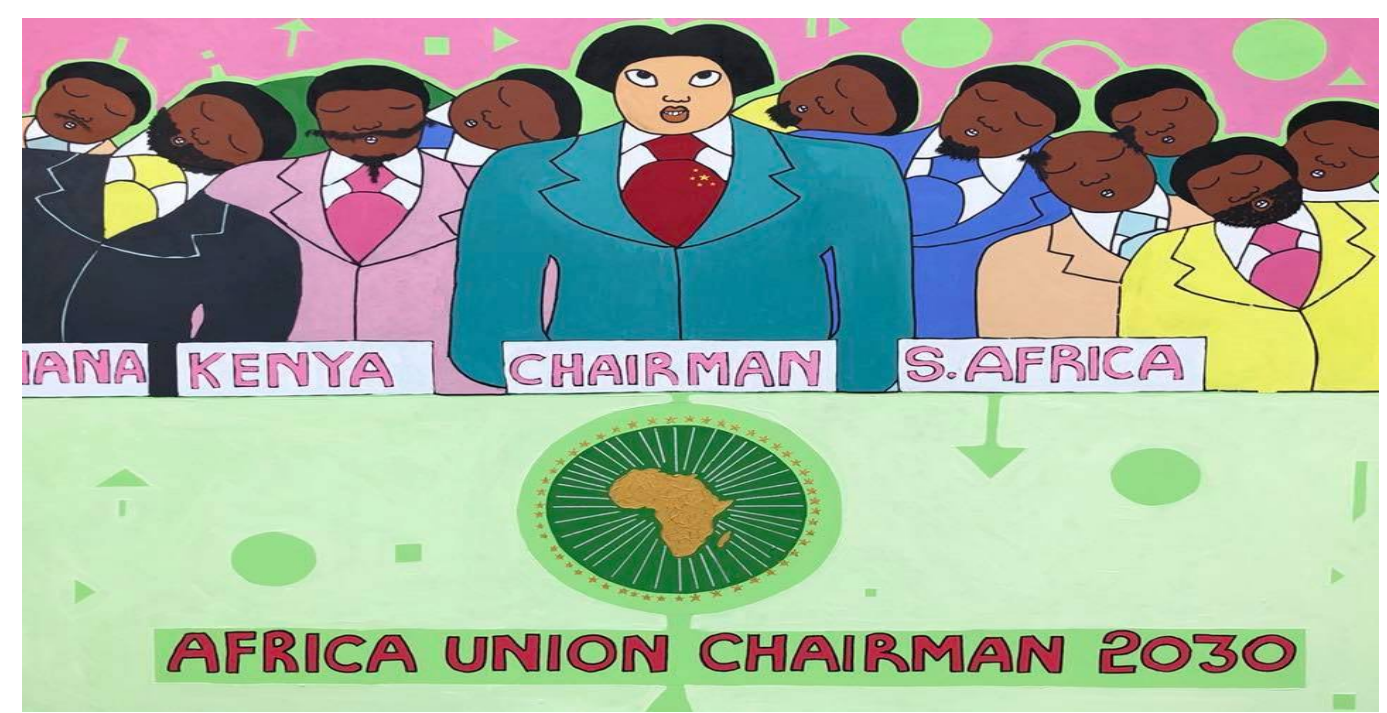

Painting ' 1 ' is Michael Soi's China Loves Africa painting captioned 'The African Union chairman 203o', acrylics mixed media on canvas, 160 by $140 \mathrm{~cm}$, added to Michael Soi studio's Facebook page on $19^{\text {th }}$ July 2018

The depiction of the ten men with deep brown facial hue, and similar hairstyles and hair-type (Afro-textured or kinky hair) is a creative technique, which enables their effective portrayal as Nubians (Black Africans). Artistically, Soi depicts one of the men as Chinese through the following creative shades. A distinctly shaped eyes, (inverted upwards), hairstyle, an oval shaped face, very light brown facial hue, and a neck tie, which depicts Chinese national flag colours and design. The placement of the Chinese in the middle of the group, with him appearing wideawake, alert, majestic, and with a physical structure indicating broader shoulders are metaphorical. Soi's depiction of the Chinese projects deliberate emphasis alluding his authority, strength and status in the group. The ten black men have no specific artistic depiction attributes that unambiguously point at who they are and the exact country they represent. Hence, Soi applies lettering whereby he adds the names of two known African countries, (S. Africa which no doubt stands for South Africa) and Kenya to enhance plausible attribution. The addition of these letterings is to indicate sufficiently that the black men are African heads of states or their respective designates, who gather under the pan-African organization platform, African Union and not just any African men from other parts of the world. The map of African and lettering 'Chairman African Union 2030' added by Soi in the painting, suggests the above supposition. Beside the lettering 'Kenya' is another lettering 'ana', which appears as an incomplete rendition/spelling of another African nation's name. We view this as deliberate attempt by Soi to imbue aesthetic significance to the painting's messages. Hence, we believe this technique aesthetically creates admirable suspense, debate and contestation, which definitely teases as well as propels speculations on the pact of the viewers of this painting. This is because among the fiftysix African countries, only two, Botswana and Ghana end with 'ana', so which one is Soi alluding.

Meanwhile, the intense lampoon in the composition is on the black men (African leaders) who are dozing. The metaphor subsumed in the dozing is that though they are effectively in an alliance with China, they are not alert to the intricacies of the alliance, which depicts their collective weakness and alarming inadequacy as leaders. In addition, the portrayal presents the leaders in slumber in broad daylight during crucial official function, as metaphorical depiction of spiritual dullness, sloth, or lack of watchfulness, which suggest deplorable state of moral and physical inadequacy. Another dense lampoon is metaphorically subsumed in the designation 
'Chairman' placed in front of the Chinese. This addition suggests that he supposedly holds the economic and political control of some Africa countries because he bankrolls their growing infrastructural development and they are in massive debt. Creative sublime essence is in the satire that is subsumed in the lettering 'Chairman' and the designation of the Chinese as such. First, it is literally improbable that a Chinese (China) will be the Chairman of African Union. However, the metaphorical supposition is that Soi's reading and consequent interpretive outcome of the SinoAfrica trade relations, propels him to postulates that by 2030 satirically though, that China will very likely be in control of Africa's major political and economic decision making. Soi is effectively applying the paintings as efficacious visual narratives to raise an alarm, in what some scholars rightly or wrongly tagged neo-colonial potentialities (see Alden 2007; Brautigam 2009; LumumbaKasongo 2011; Chen 2016; Okolo \& Akwu 2016; Langan 2017; Swedlund 2017). This is because Soi projects that since some African countries are rapidly getting heavily indebted to China, these African countries will have no choice but to resign to the dictates of China.

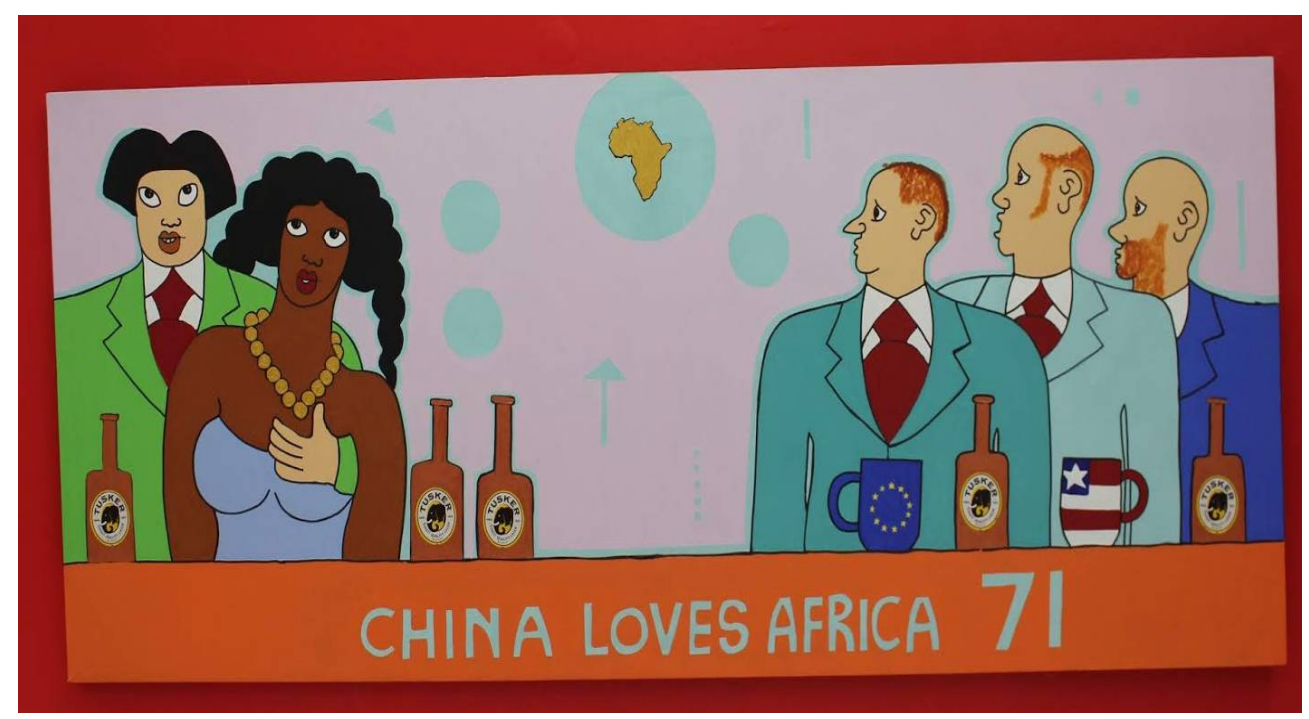

Painting '2' is Michael Soi China Loves Africa painting no. 71, Acrylic on canvas, $100 \mathrm{x} 244.5 \mathrm{~cm}$

In painting ' 2 ', there are five persons. Soi projects two of them, a male and a female as very intimate, whereas the other three males, he projects as surprised and envious observers. In the painting, Soi employs the metaphor of male (China) as the head of the family, whereas Africa is depicted as the woman partner who is expected to remain loyal to the man (China). Soi applies artistic use of facial skin hue, shape of the face and nose, colour of the hair and its style, and depiction of eyes and lips as the tools of creating suggestive realism. Thus, Soi depicts the Chinese with upward-aligned distinctive suggestive eyes, an oval shaped face, broad flattened shaped nose, and distinct hairstyle. He metaphorically designates the woman with dark brown skin hue suggestively as Africa. The other three adult male on the other side, Soi depicts as Corsicans, through their distinctive features such as lighter brown facial hue, pointy nose and tiny lips. However, because Corsicans are not all citizens of one country, Soi places two mugs with distinctive flag colours and designs as a means of designating them as representation of European Union and USA for avoidance of ambiguity. Again, the composition projects metaphorical nuances as regards to the posture of the Chinese (China) and the dark brown skin woman (Africa). The manner the Chinese is holding the woman (Africa), implies his control over her, whereas her posture suggests submission. The painting depicts metaphorically the subsisting trade ties between China and Africa, between European Economic Bloc (EU) and Africa, between 
USA and Africa, and between the other Corsican countries and Africa. On the other side which is significantly distant from the entangled Chinese (China) and Africa (the dark brown skin woman) are the three Corsicans who are also interested in the woman (Africa) but are far from possible control or takeover, because the Chinese appears to be in firm control. In addition, the facial expressions of the Corsicans project consternation to say the least, which is similar to their facial expression in painting ' 3 ' below. In support of this position, Lawal Mohammed Marafa observes that, "China is forging deep economic relationships with most African countries with the aim of securing access to their vast natural resources" (2009: 19). Furthering, he notes that, "there already exist political and military ties dating back over 50 years" and "to date, China is moving ahead with strategies that appear to have worked in its favour as a result of the neglect by traditional Western allies" (2009: 19). In addition, Marafa opines that the apparent vacuum created by the exit of West, arguably did provide the opportunity for China. For instance, "when the US evacuated its citizens in the wake of the outbreak of the Ethiopian war with Eritrea in the 1990s, China saw the reduced presence of the US as an opportunity" and China "strategically moved in with aid, grants, loans and projects" (2009: 19).

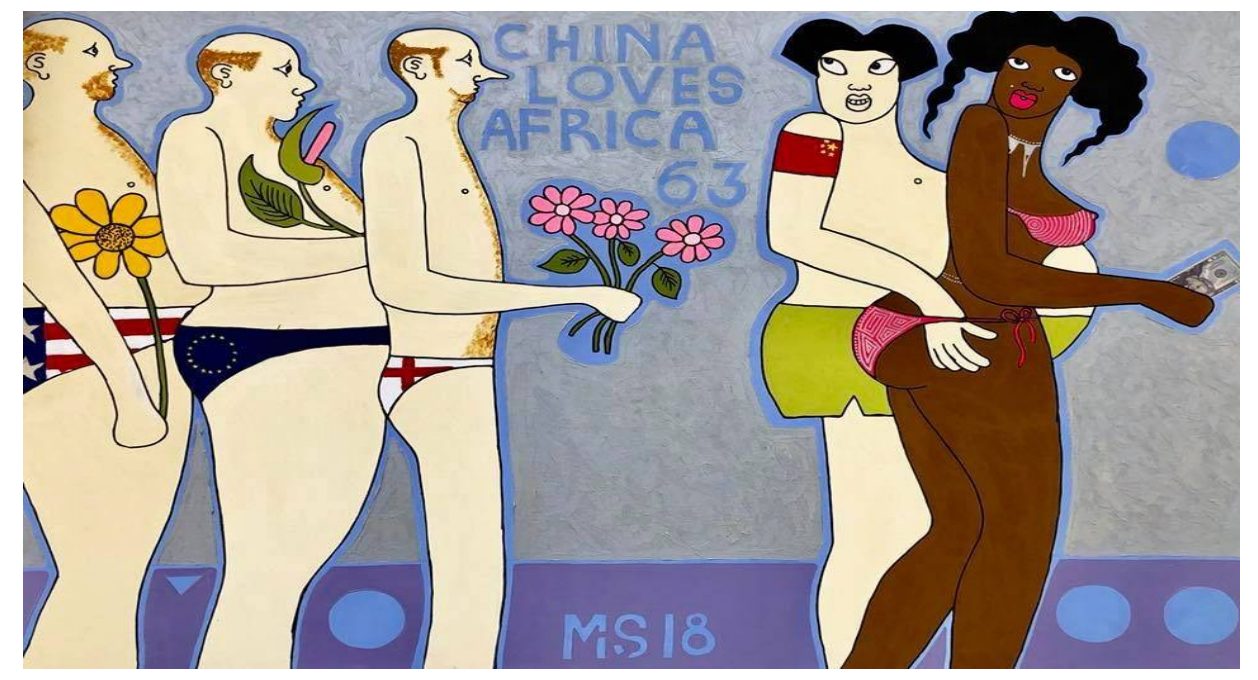

Painting ' 3 ' is Michael Soi's China loves Africa paintings no.63, Acrylics mixed media on canvas 200 by $140 \mathrm{~cm}$ added to Michael Soi studio's Facebook page on $7^{\text {th }}$ March 2018

In painting ' 3 ', Soi applies the same artistic features he deployed in painting ' 2 ' to indicate three Corsicans, representing USA, EU and Britain, Africa (the woman), and the Chinese (China). In this painting, Soi portrays metaphorically the attempts by USA, EU and Britain to woo the woman, (Africa), who is enjoying the attention and interest she is getting as the beautiful bride. The three Corsicans representing USA, EU and Britain are attempting their wooing with flower; however, their faces show their disappointment and consternation at the lack of interest by the woman (Africa). In this painting's context, the flowers symbolize emotional promises of love, which appears not to be working for the woman (Africa). We can add that since the flower each of the Corsicans is holding is different, the attribution is that their romantic promises are different. However, Soi presents the Chinese, as the one who sufficiently understands the feeling of the woman; hence, he gives her crispy currency notes, which she holds with joy, and not flowers which symbolizes mere promises. To this end, Soi presents the Chinese as one who is asserting his claim to be in deep romantic relationship with his prized acquisition, the woman (Africa), and he audaciously shows this by placing his hand in her panties regardless of who is looking and she is 
clearly not complaining. The woman holds the inducement to fall in love (currency notes) from the Chinese, which propels her to surrender her body and soul to him. Soi portrays all the Corsicans in under pants except the Chinese who is wearing a boxer short and captain armband, which metaphorically depicts him as the current leader of the park. Here, the Corsicans are making spirited attempts to woo the woman (Africa leaders), who they had in full control previously but did not continue to hold and guide devotedly hence the drastic take-over (see Alden 2007; Brautigam 2009; Lumumba-Kasongo 2011; Chen 2016; Okolo \& Akwu 2016; Langan 2017).

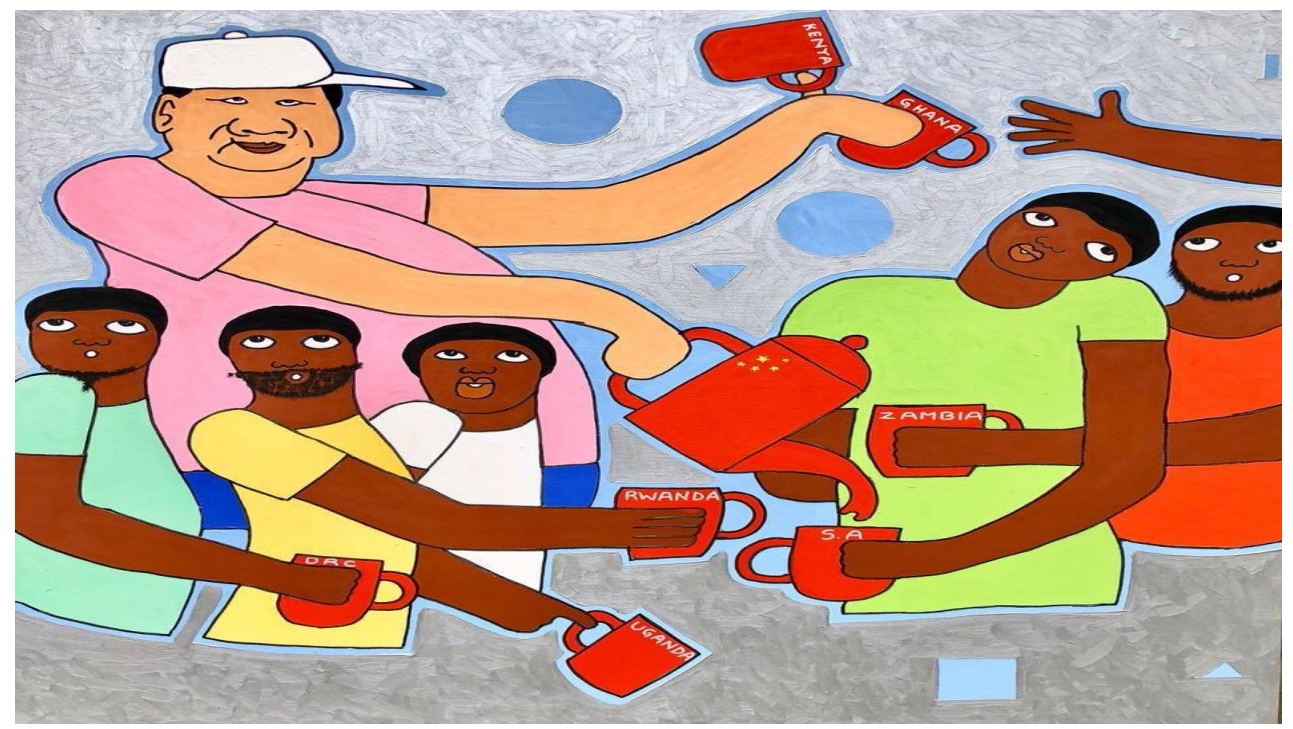

Painting '4' is China loves Africa paintings no.74, acrylics on canvas 130 by $130 \mathrm{~cm}$ added to Michael Soi studio's Facebook page on 24th July 2018

In painting ' 4 ' Soi presents a painting with six persons and he identifies them through symbolic denotations of their skin pigmentations, facial features, the inscriptions on the cups, and the design on the tea-kettle. The man holding a teakettle painted with Chinese national flag colours and design represents a metaphoric representation of China, whereas other five men represents Nubian Africans and metaphoric representations of various African Heads of States. Metaphorically, Soi depicts five African Heads of States who are soliciting and meekly extending their cups for lifeline. The Chinese with a massively protruding stomach distributes tea from the teakettle with one hand and the other extending extra cups to other willing receivers are metaphorically suggestive. Thus, the metaphorical attribution of the extended hands towards the teakettle suggests willingness on the side of Africa leaders for Chinese lifeline, which China is ready and willing to offer. The extra cups extended by the Chinese (China) suggests China's willingness to extend further lifeline to other African countries. Thus the extending of the two cups with the inscriptions Kenya and Ghana, and the extended hand without the identity of the owner hand captured in the painting, suggest the intent between both parties, a willing giver and willing receivers. The portrayal of the Chinese as an individual with massive body-size projects China as a massive source of wealth, whereas the Africans' are portrayed as a group of meekly looking persons, akin to children who dearly need the tea (lifeline). 


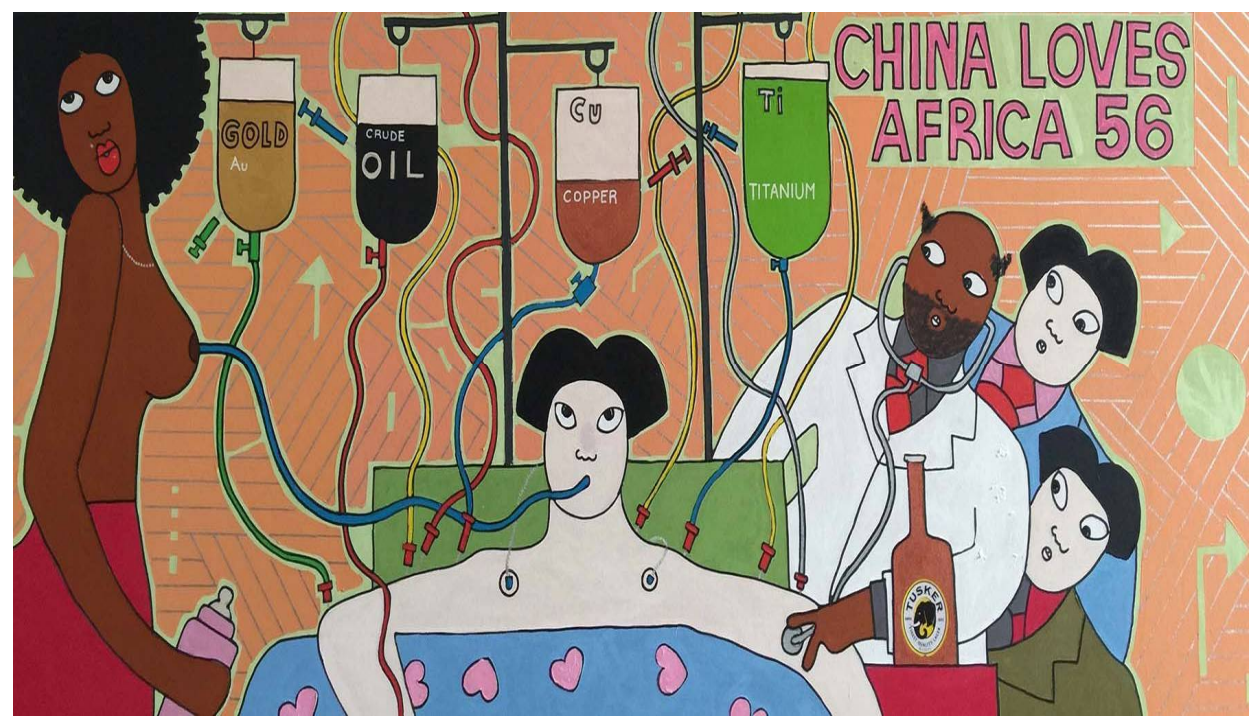

Painting ' 5 ' is Michael Soi's China Loves Africa paintings no. 56 titled 'Patient Zero', acrylics on canvas, 240 by $100 \mathrm{~cm}$, added to Michael Soi studio's Facebook page on $16^{\text {th }}$ August 2016

In painting ' 5 ', Soi presents a replication of his usual facial features symbolizing a Chinese, who appears to be in hospital bed with a black doctor, two other Chinese observers standing behind the doctor, and then a black woman standing on the other side, half nude and topless. The painting shows that the kind of drip the Chinese man is taking to keep him (Chinese economy) alive and healthy are the mineral resources found in several African countries such as gold, crude oil, copper, and titanium. The metaphor and symbolism here is that the Chinese represents China's voracious appetite for raw materials, which are in commercial quantity in several African countries. These raw materials are to keep Chinese industries, which depend on massive manufacturing for domestic and foreign exchange earning running. However, the other drips, which did not indicate the kind of mineral resources they are sending to China, we interpret as Soi's creative attempt at aesthetic suspense. However, plausible supposition suggests that there are more mineral resources from Africa, which China desperately needs, and is aiming to obtain. The density and depth of the entire metaphor in the painting revolves around the black lady who willingly allows the Chinese to suckle her breast milk through an intravenous line whereas she is readily holding a baby-feeding bottle, which signifies her readiness to baby-fed (give more 'natural mineral resources' to China). Thus, her readiness to continue to nurture the already fattening Chinese (China), whereas she appears lanky because of the relentless taking from her is in many ways, the sublime massage aesthetically subsumed. 


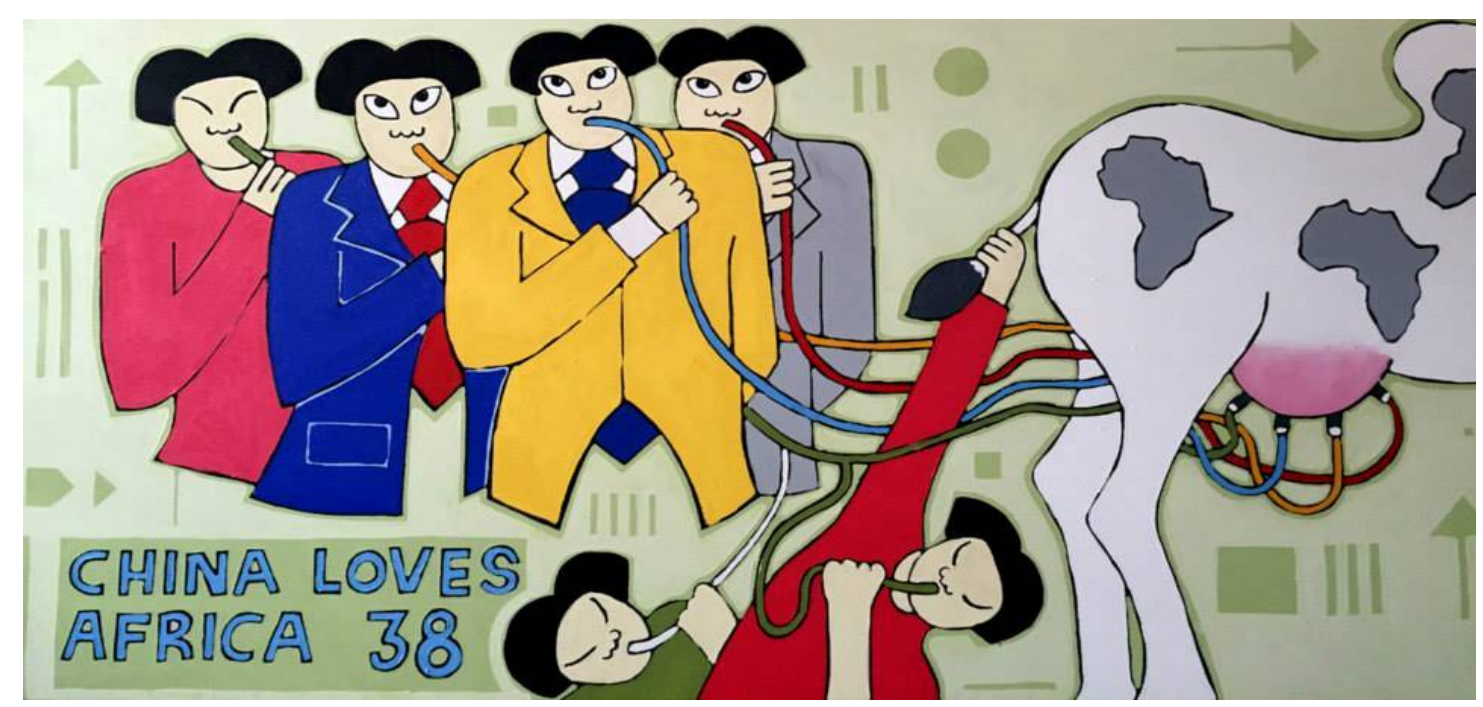

Painting '6' Michael Soi's China Loves Africa painting series no. 38, acrylics mixed media on canvas 200 by 100 cm, added to Michael Soi studio's Facebook page on $30^{\text {th }}$ April 2015

In painting ' 6 ', which depicts semiotically the same message as depicted in painting ' 5 ', Soi presents a cow as (semiotic symbolism of Africa within specific contextualization) and the six Chinese men as (semiotic metaphor representing numerous Chinese multinationals operating in African countries), who through a symbolic intravenous line (trade deals) relentlessly suck her (Africa) lean. There appear to be a symbolic cheer on their faces. This signifies positive satisfaction apparently propelled by huge profits from their business in Africa. The leanness of the cow suggests disproportional physical evidences of earnings emanating from the trade deals between China and African countries, which translate to lack of delight on the part of Africa. We can adduce that the metaphor of the hospital scene in many ways suggest that the entire trade deals between China and African countries apparently follow due process, hence legitimate, regardless of who may not be getting commensurate reward supposedly. Thus, the question is whether the lack of satisfaction and commensurate wellness on the part of Africa is because the trade deals are completely to their disadvantage or that the accrued earnings do not end up in notational treasuries accordingly. This is because paintings ' 3 ' and ' 4 ' indicate that China is not taking whatever she is taking free or illegally. Therefore, the result or benefit of the giving depicted in painting ' 3 ', where the black woman appears happy holding the wands of crisp currency notes, and painting ' 4 ', where the Chinese is sharing out tea to several African countries validate depictions in paintings ' 5 ' and ' 6 '. Thus, a number of scholars shares the inclinations presented by Soi in these paintings that more questions are begging for answers (see Sogge 2002; Tull 2006; Alden 2007; Sautman 2007; Brautigam 2009; Marafa 2009; Lumumba-Kasongo 2011; Chen 2016; Okolo \& Akwu 2016; \& Langan 2017). For instance, according to Howard W. French, when China notices that "Africa had been cast aside by the West in the wake of the Cold War" immediately she "saw the continent as a perfect proving ground for some Chinese companies to cut their teeth in international business" (2014: 2). This is because Africa remains a "repository of an immense share of global resources - raw materials that were vital both for China's extraordinary ongoing industrial expansion and for its across-the-board push for national reconstruction" (2014: 2). 


\section{Conclusion}

This study looked at how the selected paintings of Soi are efficacious mediums of communication. Our field findings suggest that politics paintings more that other art genre in many ways possess consistent powerful emotive and evocative qualities because they are more visible when they are available in public domain, and they are more interpretable than music, dance, drama, and literature. We discussed shades of artistry deployed by Soi in these paintings, which effectively project his messages. We also explained that artistic source materials are derivable from either conscious or subconscious information sources. Consequently, we note that Soi's artistic source materials are derivable from conscious information sources. We also discussed why these paintings are describable as politics paintings and what paintings of this nature achieve beyond aesthetic allure. Based on the field exercise that accompanied this study, we observe that individuals that we presented the paintings to provided similar and dissimilar interpretations and suppositions. This piece of information supports the supposition that that no two individuals possess exact quantity and quality of memory, retentive ability, recollection-logical-interpretiveanalytical capacities and information processing propensities. In addition, we argued sufficiently that these paintings in many ways represent Soi's reading and interpretation of the realities he painted. Therefore, it is logical to suggest that Soi's ideological, philosophical and worldview inclinations did influenced his projections in the paintings. Likewise, these variables are the propelling forces behind how individuals who see these paintings will react and make their interpretations. More so, we argued that the fact that these paintings elicit various reactions both poignant and pedestal, supports the notion expressed in this paper that Soi's paintings are efficacious medium of socio-political engagement, a means of sharing ideas, and a platform for meaningful commentary. Consequently, we observe that politics paintings available in the public domain possess the propensity to instigate, re-aggregate people's ideological and socio-political inclination to the extent that some who see it just might overcome fear and respond. Therefore, politics paintings can create disaffections at differing proportions, and one of the reasons why most individuals in government who feel satirically criticized through paintings will find ways to deny politics painters such as Michael Soi the opportunity to displace such works publicly.

\section{References}

Adajian, T. (2018). 'The definition of art' Stanford encyclopaedia of philosophy. Stanford: Stanford University.

Alden, C. (2007). China in Africa. London: Zed Books.

Allen, M. J. B. (1999). 'Renaissance neo-platonism' The Cambridge history of literary criticism. Vol. III: The renaissance. Glyn P. Norton, ed. Cambridge University, 436 - 438.

Amado, J. (2005). The war of the saints, trans. Gregory Rabassa, New York: Dial Press.

Bleiker, R. (2009). Aesthetics and world politics. Houndmills: Palgrave Macmillan, 18 - 47.

Brautigam, D. (2009). The dragon's gifts: The real story of China in Africa. Oxford: Oxford University Press.

Castor, G. (1964). Pléiade poetics: A study in sixteenth-century thought and terminology. Cambridge University Press.

Chen, C. K. (2016). 'China in Africa: A threat to African countries', Strategic review for Southern Africa, 38(2): $100-122$. 
Chilton, P. \& Schaffner, C. (2002). 'Introduction: Themes and principles in the analysis of political discourse' in Chilton, P. \& Schaffner, C. (eds.), Politics as text and talk: Analytic approaches to political discourse. Amsterdam: John Benjamins Publishing Company.

Danchev, A. (2009). On art and war and terror. Edinburgh: Edinburgh University Press.

Dean, J. (2003). 'The nature of concepts and the definition of art', Journal of aesthetics and art criticism 61: $29-35$.

Demirel, I. N. \& Altintas, O. (2012). 'Relationship between art and politics', Procedia - Social and behavioural sciences 51: $444-448$.

Der Derian, J. \& Michael J. S. eds., (1989). International/intertextual relations: Postmodern readings of world politics. Toronto: Lexington Books.

Dickie, G. (1974). Art and the aesthetic: An institutional analysis, NY: Cornell University Press.

Dickie, G. (1984). The art circle. NY: Haven Publications.

Dickie, G. (1997). Introduction to aesthetics: An analytic approach. NY: Oxford University Press.

Drucker, J. (2005). Sweet dreams: Contemporary art and complicity. Chicago: University of Chicago Press.

Eagleton, T. (1990). The ideology of the aesthetic, London: Basil Blackwell.

Eagleton, T. (2000). The idea of culture. Oxford: Blackwell.

Eckert, C. \& Martin, S. (2000). Sources of inspiration: A language of design. Design studies, 21(5): 523-538.

Elderfield, J. (2006). Manet and the execution of Emperor Maximilian. NY: Museum of Modern Art.

French, W. H. (2014). China's second continent. New York: Alfred Knopf.

Goehr, L. (20140. 'Art and politics', The Oxford handbook of aesthetics. Levinson, J. (ed), Oxford: Oxford University Press.

Gorman, D. (2015). The art of disobedience: Arts and politics. Fresh perspectives, No.3, https://www.ietm.org/en/fresh-perspectives-3-art-of-disobedience, 1 - 25.

Groys, B. (2008). Art power. Cambridge: The MIT Press.

Haas, S. (2011). Can art influence political policy on the environment: A case study examining Rolf Groven's eco-art, MPhil Thesis, Centre for Development \& the Environment University of Oslo Blindern, Norway.

Hurlburt, L. P. (1989). The Mexican muralist in the United States. Alburquerque: University of New Mexico Press.

Ittmann, J. (ed) (2006). Mexico and modern printmaking: A revolution in the graphic arts, 1920 to 1950. Philadelphia: Philadelphia Museum of Art.

Janaway, C. (1998). Images of excellence: Plato's critique of the arts, Oxford: Oxford University Press.

Kostopoulos, C. (2011). The art of politics, or the politics of art? Conceptualizing aesthetic commitment from within a Ricoeurian framework. Art, emotion and value. 5 th Mediterranean congress of aesthetics. https://www.um.es/vmca/proceedings/docs/23.Candess-Kostopoulos.pdf

LaCapra, D. (2004). History in transit: Experience, identity, critical theory. NY: Cornell University Press

Langan, M. (2017). 'Emerging powers and neo-colonialism in Africa' in Langan, M. (ed.), Neo-colonialism and the poverty of 'development' in Africa, Palgarve Macmillan, Newcastle, 89 - 117.

Levinson, J. (1990). Music, art, and metaphysics, Ithaca: Cornell University Press. 
Lumumba-Kasongo, T. (2011). 'China-Africa relations: A neo-imperialism or a neo-colonialism? A reflection', African and Asian studies, 10: 234 - 266.

Marafa, L. M. (2009). Africa's business and development relationship with China: Seeking moral and capital values of the last economic frontier, Discussion paper 44, Nordiska Afrika Institutet, Uppsala, 1-23, https://www.diva-portal.org/smash/get/diva2:272966/FULLTEXTo2.pdf

Mattick, P. (2003). Art in its time: theories and practices of modern aesthetics. London: Routledge.

McLean, I. \& McMillan, A. (2009). Oxford concise dictionary of politics. Oxford: Oxford University Press.

Mitchell, W. J. T. (1994). Picture theory: essays on verbal and visual representation. London: University of Chicago Press.

Möller, F. (2018). Politics and art. Oxford: Oxford University Press.

Okada, T. \& Ishibashi, K. (2017). 'Imitation, inspiration, and creation: Cognitive process of creative drawing by copying others' artworks', Cognitive science. 41(7): 1804 - 1837.

Okolo, A. L. \& Akwu, J. O. (2016). 'China's foreign direct investment in Africa's land: hallmarks of neocolonialism or South-South cooperation', Africa review, 8(1): $44-59$.

Okpara, C., Aniago, E., \& Okpara, T. F. (2020). 'Metaphor and melancholy consciousness: enduring efficacy and universal common in Obiora Udechukwu's eight paintings' Rupkatha journal on interdisciplinary studies in humanities, 12(6): $1-15$.

Oppler, E. C. (1988). Picasso’s Guernica. New York: WW Norton.

Patel, A. A. (2016). 'Laryngology in art: the portrait of Dr Wilhelm Mayer-Hermann', Otolaryngology-head and neck surgery, 155(6):1012 - 1013.

Ranciere, J. (2010). 'Dissensus: On politics and aesthetics' Edited \& Translated by Steven Corcoran. London: Continuum International Publishing Group.

Rhodes, R. (2013). 'Guernica: Horror and inspiration', Bulletin of the atomic scientists, 69(6): 19 - 25.

Sautman, B. V. (2007). 'Friends and interests: China’s distinctive links with Africa' Working paper No.12, Centre on China's transnational relations. Hong Kong University of Science and Technology.

Shapiro, M. J. (2013). Studies in trans-disciplinary discourse after the aesthetic turn. London: Routledge.

Shiner, L. (2001). The invention of art, Chicago: University of Chicago Press.

Singh, C. (2012). Biography and the educative: A critical examination of the life and artwork of Wilhelm Heinrich Otto Dix, PhD Thesis, Faculty of Human and Social Sciences, University of Southampton, UK.

Sogge, D. (2002). Give and take: What's the matter with foreign aid? NY: Zed.

Swedlund, H. J. (2017). 'Is China eroding the bargaining power of traditional donors in Africa', International affairs. 93(2): 389-408.

Tan, E. S. (200o). 'Emotion, art \& the humanities' Handbook of emotions, $2^{\text {nd }}$ Ed, Lewis, M. \& HavilandJones, J. M. (Eds.), New York: Guilford Press, 116 - 136.

Tull, D. M. (2006). 'China's engagement in Africa: Scope, significance and consequences', Journal of modern African studies, 44(3): 459 - 79 .

Weitz, M. (1956). 'The role of theory in aesthetics', Journal of aesthetics and art criticism, 15: 27 - 35. 
16| Rupkatha Journal, Vol. 13, No. 1, 2021 